Review Article

\title{
Food Waste Treatment Methods and its Effects on the Growth Quality of Plants: A Review
}

\author{
Veknesh Arumugam¹, Muhammad Heikal Ismail ${ }^{1 *}$, Tharsini Amma Puspadaran², \\ Winny Routray ${ }^{3}$, Ngadisih Ngadisih ${ }^{4}$, Joko Nugroho Wahyu Karyadi ${ }^{4}$, Bambang $^{2}$ \\ Suwignyo $^{5}$ and Hatma Suryatmojo ${ }^{6}$
}
${ }^{1}$ Department of Chemical and Environmental Engineering, Faculty of Engineering, Universiti Putra Malaysia, Serdang, 43400 Malaysia
${ }^{2}$ Micron Technology (M) Sdn Bhd, 5, Jalan BPU 7, Bandar Puchong Utama, Puchong, 47120 Malaysia
${ }^{3}$ Department of Food Process Engineering, National Institute of Technology Rourkela, Odisha, 769008 India
${ }^{4}$ Department of Agricultural and Biosystems Engineering, Faculty of Agricultural Technology, Universitas Gadjah Mada, Yogyakarta 55281 Indonesia
${ }^{5}$ Department of Animal Nutrition and Feed Science, Faculty of Animal Science, Universitas Gadjah Mada, Yogyakarta 55281 Indonesia
${ }^{6}$ Department of Forest Resource Conservation, Faculty of Forestry, Universitas Gadjah Mada, Yogyakarta 55281 Indonesia

\begin{abstract}
Food waste and leftovers were common materials that were currently used as biocompost or soil conditioners upon decomposition. Food waste was a source of food that has declined nutritional value and is not deemed favorable for human consumption.

ARTICLE INFO

Article history:

Received: 28 July 2021

Accepted: 18 October 2021

Published: 21 December 2021

DOI: https://doi.org/10.47836/pjtas.45.1.05

E-mail addresses:

viknesharumugam2@gmail.com (Veknesh Arumugam)

heikal@upm.edu.my (Muhammad Heikal Ismail)

tharsiniamma@gmail.com (Tharsini Amma Puspadaran)

routrayw@yahoo.com (Winny Routray)

ngadisihugm@gmail.com (Ngadisih Ngadisih)

jknugroho@ugm.ac.id (Joko Nugroho Wahyu Karyadi)

bsuwignyo@yahoo.com (Bambang Suwignyo)

hsuryatmojo@ugm.ac.id (Hatma Suryatmojo)

*Corresponding author

Leftovers were defined as uneaten edible remains of a meal. Biodegradation of these components contributes to many macronutrients, including carbon (C), hydrogen $(\mathrm{H})$, nitrogen $(\mathrm{N})$, phosphorus $(\mathrm{P})$, and potassium $(\mathrm{K})$ in the compost, which makes it a suitable growing condition for plants. In this study, the main sources of research data were one hundred thirty-one scientific articles relating to food waste treatment methods and the growth quality of plants over the last few years. This review was the consensus of the role and
\end{abstract}


Veknesh Arumugam, Muhammad Heikal Ismail, Tharsini Amma Puspadaran, Winny Routray,

Ngadisih Ngadisih, Joko Nugroho Wahyu Karyadi, Bambang Suwignyo and Hatma Suryatmojo

characteristics of food waste and leftovers as fertilizers. Moreover, the paper briefly discusses the different composting methods for these materials and their corresponding effects on the growth quality of plants.

Keywords: Composting, food waste, food waste treatment, leftovers, plant growth

\section{INTRODUCTION}

Food waste is a complex problem that can affect the various elements of sustainability, including climate, economic and social conditions (Food and Agriculture Organization of the United Nations [FAO], 2013), apart from directly depriving the food and nutrition availability to a huge population. Approximately 1.32 billion metric tons of food, approximately onethird of consumption food, was missing and wasted (FAO, 2011). Furthermore, municipal solid waste (MSW) management,

\section{Table 1}

Amount of food waste generated in different countries in 2010 (Melikoglu et al., 2013)

\begin{tabular}{lc}
\hline Country & $\begin{array}{c}\text { Food waste generation } \\
\left(\mathrm{x} 10^{6} \text { tons }\right)\end{array}$ \\
\hline United & 79.0 \\
States & \\
United & 11.0 \\
Kingdom & \\
Singapore & 0.6 \\
Japan & 19.0 \\
Taiwan & 16.5 \\
Korea & 4.3 \\
\hline
\end{tabular}

which most developed countries face, was difficult. The world's biggest organic waste was food waste, accounting for roughly $30.7 \%$ (Kadir et al., 2016). Table 1 shows the amount of food waste generated in different countries in 2010. Melikoglu et al. (2013) stated that Asian countries could further increase their annual urban food waste volume from 278 to 416 million tonnes between 2005 and 2025. Table 2 shows the amount of food waste generated in Malaysia. Food loss can be categorized as (1) food waste, which was generally the degraded form, and (2) food by-products that were obtained through the removal of food from the food supply chain (FAO, 2014). For developing countries, food waste in the early stage of the production chain was a problem, whereas leftovers are primarily observed as the problem for developed countries.

\section{Table 2}

Amount of food waste generated in Malaysia (Jereme et al., 2016)

\begin{tabular}{lc}
\hline Sources of food & $\begin{array}{c}\text { Food waste } \\
\text { generation } \\
\text { (x106 tons/year) }\end{array}$ \\
\hline Households & 3.192 \\
Wet and night & 2.040 \\
markets & 1.941 \\
Restaurants & 0.572 \\
Hotels & 0.108 \\
Shopping malls & 0.106 \\
Hypermarkets & 0.311 \\
Food industries & 0.021 \\
Schools & \\
\hline
\end{tabular}


Leftovers have a higher percentage of disposal than food waste; this situation can be observed in the Netherlands, in which leftovers attributed to consumers recorded at $10-15 \%$ of the total waste (Toumi, 2017). The various research reviews aid in progressive learning, as it includes the latest approach and recommendations that can be very insightful for the research. Hence, this review paper focused on summarizing the application of food waste and leftovers as compost and the different approaches adopted by fellow researchers in studying the properties and characteristics of this organic compost. In the first part of the review, different methods used to compost the food waste were summarized based on the published articles and research papers. The second part of the review discussed the available practices to measure compost nutrient quality. The sequential order has been followed to promote a sheer focus on each stage. Furthermore, it was so that the appropriate food waste treatment method could be distinguished and selected as a convenient reference for future research studies.

Food that has been dumped and disposed of can be segregated into two categories as (a) food waste and (b) leftovers. To begin with, food waste, otherwise known as pre-consumer food, was the category of food obtained from kitchen areas of restaurants and households. These wastes largely include meal prep waste, such as vegetables and fruit seeds and peelings. Unservable food and its residues, such as coffee grounds, were also included in this category.
Moreover, these wastes also include foods that perish during the production process, transportation process, and excess food that has expired in supermarkets and bakeries (Bashir et al., 2013; Blakeney, 2019; Heikal Ismail et al., 2020; Muruga et al., 2021). The category of leftovers usually includes the food residues left on plates disposed of by the consumers. These wastes were also known as post-consumer food, and they usually included domestic foods that had been discarded and were often co-mingled with yard debris upon disposal. This food waste can often be spotted in a large amount in dining restaurants, buffets, and hotels (Ebner et al., 2014).

Food waste and leftovers were biodegradable wastes discharged from various sources, including food processing industries, hospitality sectors, and households (Paritosh et al., 2017). A total amount of approximately $90 \%$ of food waste was biodegradable. These waste products have remarkable qualities, and they have high moisture content and a physical shape that can quickly be decomposed (Paritosh et al., 2017). Food-based compost was a good alternative composting source because of the high organic content matter, high moisture content, and the ratio of carbon to nitrogen $(\mathrm{C} / \mathrm{N})$ content for waste in residues. In the cases of post-consumer food leftovers, handling these wastes has been observed as a more laborious process attributed to the separation process that needs to be conducted for efficient utilization since the wastes were often subjected to contaminants upon disposal (Risse \& Faucette, 2009). 
Veknesh Arumugam, Muhammad Heikal Ismail, Tharsini Amma Puspadaran, Winny Routray,

Ngadisih Ngadisih, Joko Nugroho Wahyu Karyadi, Bambang Suwignyo and Hatma Suryatmojo

The ratio of carbon to nitrogen was one of the key dimensions that can impact the composting cycle and the product properties (Amin, 2011; Apagu, 2012). Hence, since leftovers were often subjected to contaminants, calculating the optimized ratio of $\mathrm{C} / \mathrm{N}$ while including possible impurities present in the waste can be difficult. Conversion of waste to compost was also essential as it was a beneficial lowcost method and maintenance compared to incineration and land disposal.

\section{FOOD WASTE TREATMENT METHODS}

\section{Discarding in the Landfill}

Food waste treatment using the landfill approach was the most common waste management strategy (Jayaprakash et al., 2018). Based on a report by the Environmental Protection Agency (EPA) (2017) in the site of landfills, the volume of municipal solid wastes fell to 135.5 million tons in 2010, from 145.3 million tons in 1990 . The fell was caused by a surge of waste recovery through recycling and composting utilized as energy recovery. However, many negative impacts have been linked to landfill disposal in which leachate contamination could contaminate rivers and seas (Abdul Jalil, 2010; Abdullah \& Chin, 2010) and lead to groundwater contamination (Lih, 2015).

Hydrogen sulfide $\left(\mathrm{H}_{2} \mathrm{~S}\right)$ was one of the major odors causing compounds in landfill gas and could cause environmental and health impacts (Du et al., 2014). The concentration of $\mathrm{H}_{2} \mathrm{~S}$ ranges from 100 micrograms per cubic meter up to 1000 milligrams per cubic meter in various municipal solid waste landfill sites. Besides pollution, the high living expenses due to the growing budget for landfill management was also one of the growing concerns faced soon (Muhammad Firdaus et al., 2018). Moreover, the formation of leachate was a big issue that must be considered in the sanitary landfill. These were the wastewater extracts from the soil (Kasozi et al., 2009).

\section{Incineration}

As for incineration of waste, this method has a high capability of releasing dioxin gases, which are highly toxic and can threaten human health (Paritosh et al., 2017). Food waste treatment using incineration was also another approach that was being widely used. However, this method has been reported to consume a huge amount of energy compared to other waste treatments used to produce thermal energy that greatly reduces the wastes' volume. In addition, high moisture and salt content in food waste can reduce the lifecycle of the incinerator, and it directly accounts for the release of dioxins. Therefore, incineration was also considered a potential environmental impact and public health risk (Chen, 2016). Besides, the huge energy supply needed incineration also requires a high cost to be set up and utilized (Bong et al., 2017).

\section{Anaerobic Digestion}

Anaerobic Digestion (AD) was a process that produces biogas through microbiological digestion of organic matter in an anaerobic 
condition. This treatment approach focuses on recycling, recovery, and a reduction system of landfill disposal method (Palaniveloo et al., 2020). The factors that promote this method are environmentalfriendly, renewable fuel, and low cost. Anaerobic microbes' functions to convert organic wastes and biomass into biogas, which consists of $70 \%$ methane, 30 to $40 \%$ carbon dioxide $\left(\mathrm{CO}_{2}\right)$, and traces of hydrogen $\left(\mathrm{H}_{2}\right)$ and $\mathrm{H}_{2} \mathrm{~S}$ (Warman et al.,
2009). The food-based raw material was suitable for an anaerobic digestion process due to its composition and moisture content. The by-product of this process is called digestate, or organic solids with a high content of nutrients and are suitable for use as fertilizer or compost (Yang et al., 2014). There were four main stages involved in anaerobic digestion, and the process is as shown in Figure 1.

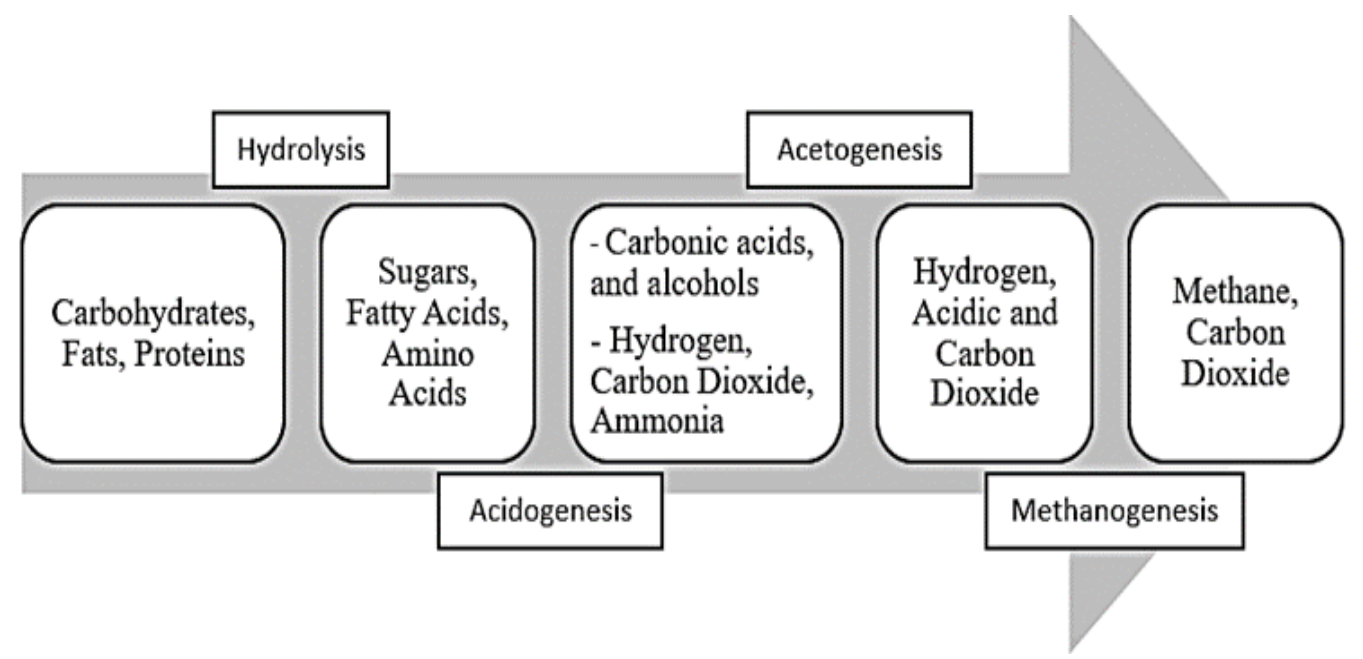

Figure 1. Process stages of anaerobic digestion

\section{Composting}

Composting was defined to create a solid humus-like substance to biologically degrade organic materials under controlled aerobic conditions (Cabanillas et al., 2013). Compared to the other waste treatment approach, composting was gaining more interest as it was economically and environmentally beneficial. Composting was one of the biological waste treatments widely treated as a natural and sustainable appropriate organic waste management (Garnett, 2012). This process occurs naturally, provided that microbial growth is possible with the right species, moisture, aerobic environments, feed, and nutrients. The composting mechanism will proceed even more easily by managing these variables. When composted, waste was broken down into a blend of soil conditioning. 
Veknesh Arumugam, Muhammad Heikal Ismail, Tharsini Amma Puspadaran, Winny Routray,

Ngadisih Ngadisih, Joko Nugroho Wahyu Karyadi, Bambang Suwignyo and Hatma Suryatmojo

It lowers the volume of deposits entered by almost $18 \%$. Composting was important for this solution to be developed and for reducing solid waste, including food waste.

A case study conducted in Denmark to study the life-cycle analysis and benefits of home composting of food waste suggested that this replacement of fertilizer might significantly benefit the environment. In addition, research comparing the efficacy of a few organic fertilizers and chemical fertilizers on the growth rate of watermelon (Citrullus lanatus) has been performed. The analysis concluded with organic fertilizers showed the highest results regarding the consistency parameters of the watermelon's redness and rind thickness (Massri \& Labban, 2014). Furthermore, composting was also a technology that was simpler to incorporate and less expensive than other technical approaches (Íñiguez-Covarrubias et al., 2018).

In application, the composted food waste can be used as fertilizer, biogas, or feed mills to produce animal pellet feed. The $\mathrm{C} / \mathrm{N}$ ratio of the composted substance was a critical variable that needs to be considered in composting, and the favorable ratio ranges from 25-30:1 (Hanc et al., 2014). The location consideration of composting site should be located near landfill to reduce material handling and ease operations. However, there were certain drawbacks associated with composting. The main drawback that has been observed in a Norwegian study was to produce a stable matured compost and the unpleasant odor produced from the composter (Chen, 2016).
Besides that, there were arguments that state that the composting process reduces the overall greenhouse gas emissions, and others claimed that it increases greenhouse gas emissions.

\section{Different Methods of Composting}

Pit/Heap Method. The pit method was conducted by piling and turning the waste once or twice a week for adequate aeration. This method was also known as windrow or trench composting. The advantage of this method includes (Paritosh et al., 2017):

Little expense-Only requires kitchen scraps (or any other food wastes sources), the pile of leaves, and grass clippings as the materials to begin composting. Then, there will be no expenses on compost space as it will be conducted in the soil.

On-site compost-The compost will ordinarily be conducted in garden space, making it easier to transfer the compost to the plants once it has matured.

This method was primarily encouraged if there was an abundance of free land space to conduct it. In the cross-section of this composting site, the shape of the windrow diversifies from rectangular, trapezoidal, and triangle, as shown in Figure 2.

The shape and size of the pit highly depend on the composting materials and the equipment used for turning. However, based on a study conducted, the minimum area required for a composting unit was $1.25 \mathrm{~m} \mathrm{x} 1.25 \mathrm{~m}$. The pile will be typically mixed and turned with a pitchfork to lift and loosen the pile. At times, the compost pile's temperature was monitored and turned at a 


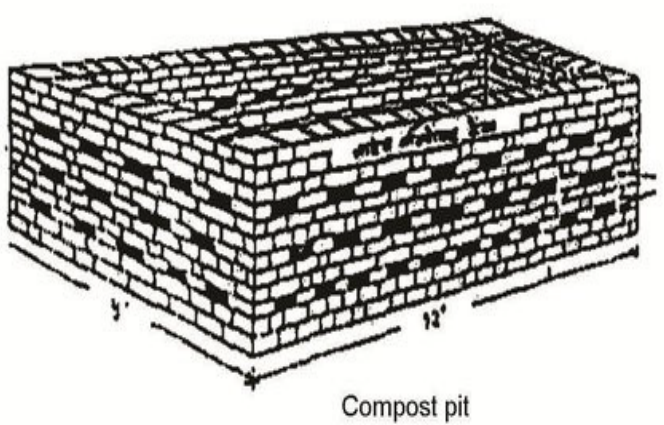

Figure 2. The visual aspect of compost pit

certain temperature range, usually around $55^{\circ} \mathrm{C}$ to $60^{\circ} \mathrm{C}$ (Khater, 2015). In addition, based on the research conducted by Edwards (Edwards et al., 2008), to prevent leakage of nutrient-rich solution from the pile, the bottom and sides of the base of the trench need to be watered. However, it does come along with certain drawbacks. The compost pile smell can easily attract those pests, and there was no reliable method to keep them away from it. However, the pit-based method was also labor-intensive (Praveen, 2009).

Aerated Statis Piles. Aerated static pile (ASP) was a method of compost in which air was introduced to the stack pile through perforated pipes and blowers (Figure 3). ASP was an improvised version of windrow composting in which airflow was provided underneath to supply oxygen to prevent anaerobic conditions. The need to transform the compost heap into the compost pile was removed by causing airflow. This system was

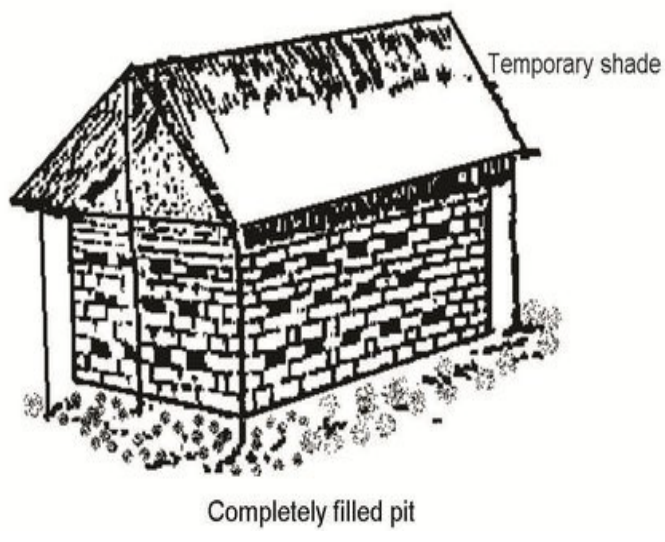

well adapted for different feedstocks, such as green waste, cooking waste, biosolids, and animal dung. The aerobic condition of the compost can be maintained by controlling airflow throughout the compost pile. Composting and aeration of a manually aerated pile were primarily seen in Korean farms. Based on a study on the effects of aeration rate on compost quality, the results show that low and medium aeration rate has a higher impact in obtaining an optimal nitrogen concentration in the compost.

Proper temperature sampling in the ASP method was essential to produce a good quality compost pile. At a temperature of $44.7^{\circ} \mathrm{C}$ under proper conditions of adequate oxygen supply, the pile began to decompose (Andersen et al., 2012; Apagu, 2012). The pile forming takes place on a network of drilled pipes for the front loader. The perforation of tubes was arranged in two rows of perforation placed in parallel to each other. This method commonly requires no labor. However, the ASP approach was 
Veknesh Arumugam, Muhammad Heikal Ismail, Tharsini Amma Puspadaran, Winny Routray,

Ngadisih Ngadisih, Joko Nugroho Wahyu Karyadi, Bambang Suwignyo and Hatma Suryatmojo

weather-sensitive, and this design could also cause fluctuation in pathogen concentration due to inconsistent mixing. This method also implies high cost, and it was not suitable to decompose grease-based substances and animal manure (Risse \& Faucette, 2009).

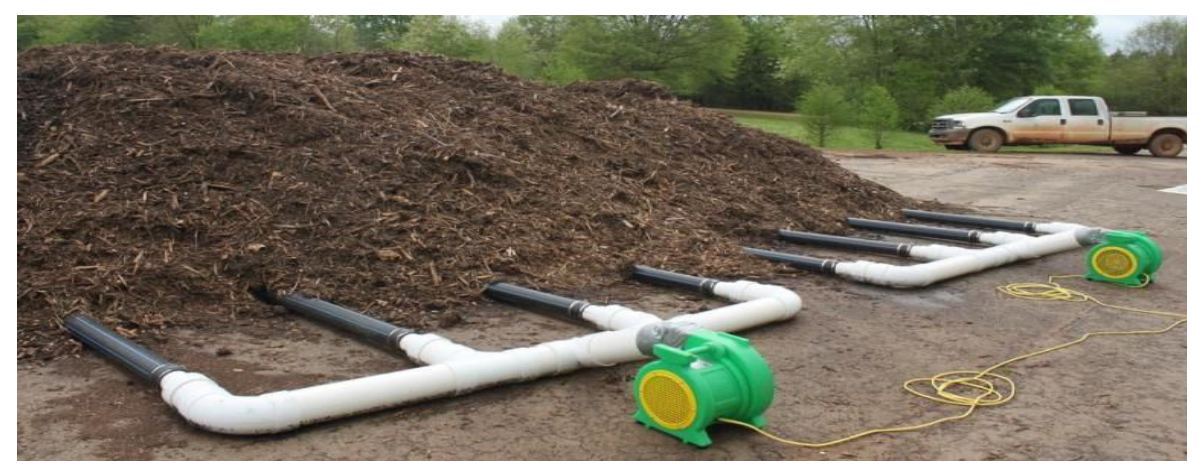

Figure 3. The visual aspect of the aerated statis piles method

Compost Bin and Box. Compost bins, also known as in-vessel systems, used drums, perforated barrels, and specially designed containers to ease the composting process, as shown in Figure 4. This invessel system performs compost processes primarily in drums or channels designed to have optimal conditions, using a highrate controlled aeration device. Compost bins were home composting systems that were frequently compared to the industrial composting system on the aspects of energy consumptions and environmental burdens. A home-oriented compost bin was potentially environmentally beneficial as collection and transportation of bio-waste can be avoided (Pandey et al., 2016).

An improved compost bin design needs to be produced to eliminate the indiscriminate release of greenhouse gas during the composting process for better performance. Besides bin, compost box was another approach that follows container usage to decompose food residues. The method that was prominent in this category was the Takakura portable compost boxes. This technique treated food waste in offices and universities (JiménezAntillón et al., 2018). The Institute for Global Environmental Strategies in Japan conceived and developed the strategy in

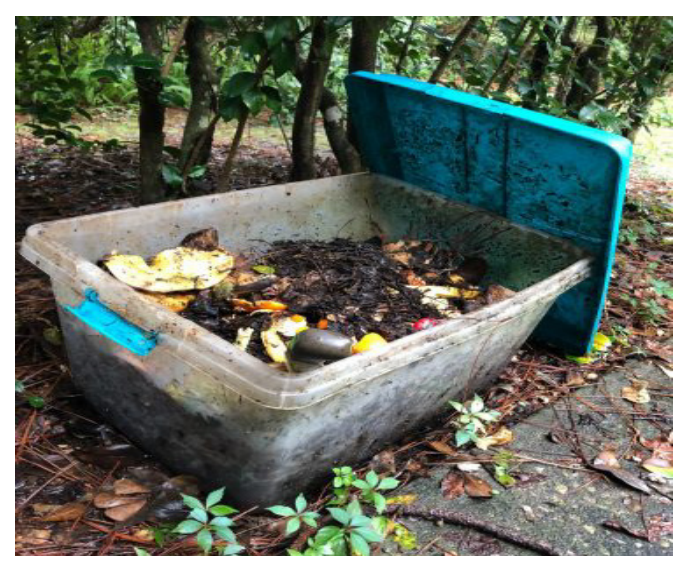

Figure 4. Compost bin/box 
2010. This approach has been practiced in an estimated 40,000 households in the city area of Surabaya, Indonesia. The amount of solid waste in that city that has been reduced by practicing this method was about $30 \%$ (Kurniawan et al., 2013). However, despite the benefits, there was a couple of weakness that can be observed. The weakness was as stated below (Íñiguez-Covarrubias et al., 2018; Lekammudiyanse \& Gunatilake, 2008):

- Time-consuming-The process of feeding the Takakura compost box requires a long time to be conducted due to chopping materials before adding them to the box.

- Hefty maintenance-The outer part of the compost box should be cleaned frequently to prevent odors, insects, and pests.

Implementing biochar in this method has also proven to improvise the compost quality and rate of production. Biochar as an alternative additive in the compost bin helps to promote the fermentation process of compost. Dead leaves and cuttings were used to produce biochar, decorative plant waste, and cocoa leaves. Lawn waste was used as a bulking agent in the composting process. Based on the study conducted on the effectiveness of biochar on food compost, in the product, biochar had raised the concentration of ammonium $\left(\mathrm{NH}_{4}\right)$ by 37.8 to $45.6 \%$ and nitrate $\left(\mathrm{NO}_{3}\right)$ by 50 to $62 \%$ (Waqas et al., 2018).
Compost Tumbler. Compost tumbler was almost like compost bins. Despite the similarity, compost tumbler was a better way to aerate the compost without physically exerting energy to turn the compost itself. Figure 5 shows the aeration that occurred in the compost tumbler. This tumbler system can be formed by using trash cans or soap barrels to construct it. As for the mechanical properties, proper rotation in composting machines of this method was a successful technique that produces an actual product because of proper stirring, aeration, and compost mixtures (Rich \& Bharti, 2015). The material design for this composter was made up of light metal to allow the tumbler's rotation to be easy.

For the compost tumbler method, microorganisms and enzymes were used as additives according to the recommended measurement. Compost additives help boost composting processes, soil microand macronutrient quality, soil nitrogen, phosphorus, and potassium concentrations (Jayaprakash et al., 2018). The tumbler compost machine was widely used because of the turning accessibility that provides equal ventilation to the compost. However, the drawback of this system was that there was no specific moisture and temperature levels measurement system essential to monitor the compost. Therefore, it was essential to observe the compost from time to time to know if it was too dry, too wet, or not to heat up. In addition, manufactured compost tumblers were costly than the compost bins and piles method (Thenabadu et al., 2015). 


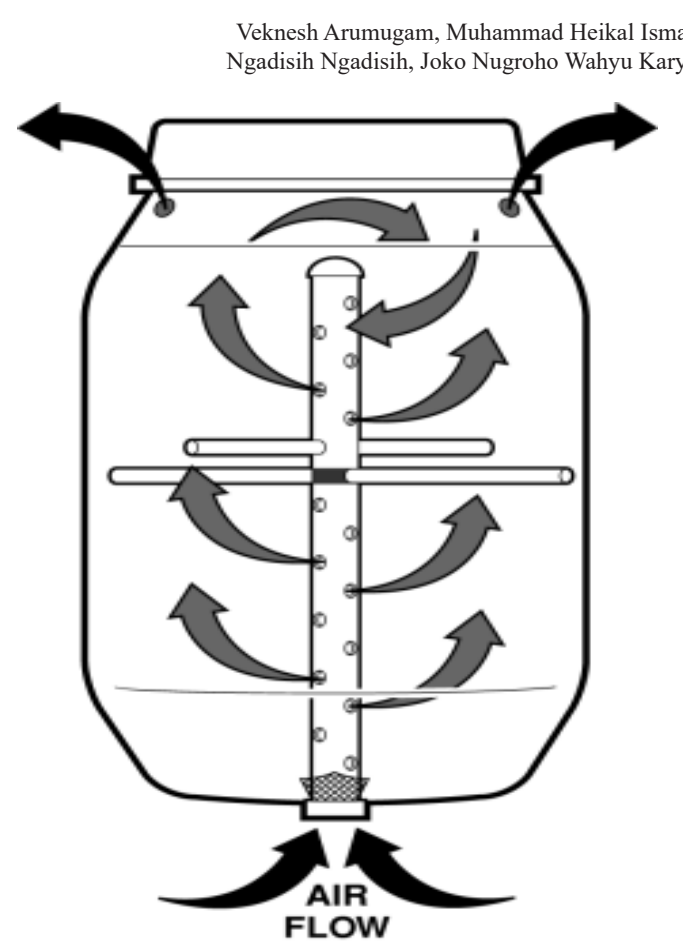

Figure 5. The visual aspect of compost tumbler

Solar Digester. The solar digester was an approach that operated well in confined spaces, such as black plastic or metal drum. The solar energy utilization stimulated the photosynthetic process in these applications. One of the prominent solar digesters that were being used was called the Green Cone technology. This compost equipment was produced and designed in Ontario, Canada since the year 1988. This equipment consists of plastic, with a top-shaped cone and attached basket in which the food was stored underground under the cone, as shown in Figure 6. In Greece, this idea of solar digester has been utilized by constructing digester below ground level and covered with flat-plate solar collectors at the roof structure. The steps for this process were to insert the food waste through the hinged lid, and it will fall into the container. The fungi, bacteria, microorganisms, worms, and insects must decompose the food scraps in this stage. The positive quality of this system was that $90 \%$ of the input was absorbed into the surrounding soil as a compost water source to the plant. Nevertheless, the setback for this approach was that it only disperses compost within a particular area of land, and the dispersion cannot be manipulated and controlled (Mu et al., 2017).
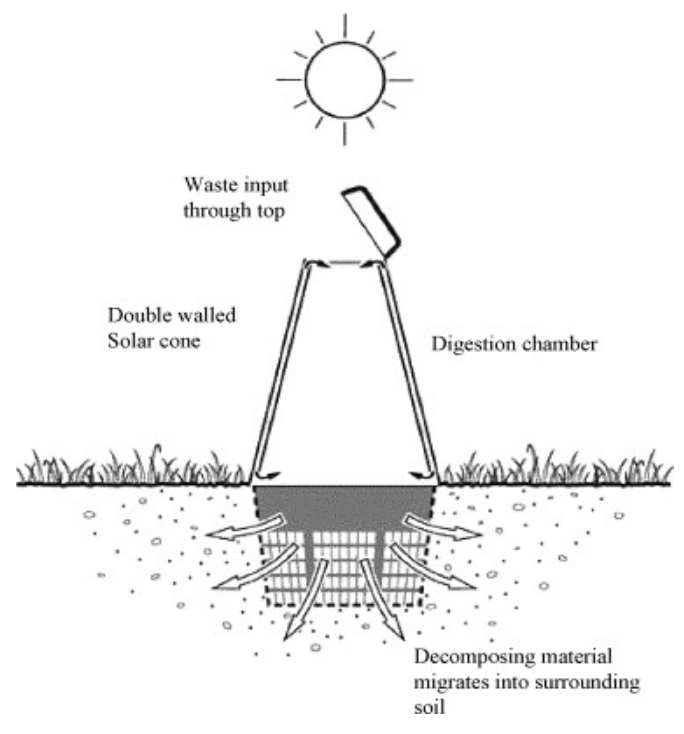

Figure 6. The visual aspect of solar digester

Vermicomposting. Vermicomposting was a composting technique that utilizes various species of worms to decompose the food scraps. This method was also widely regarded as a clean and sustainable approach to dealing with organic waste (Bong et al., 2017). Then, this approach was also an eco-friendly, eco-biotechnological, and 
bio-oxidative application mechanism that stabilized the waste into functional bioproduct (Saer et al., 2013). Vermicomposting amplifies the usage of worms to digest the food waste into compost. It appears to be an excellent alternative because worm casts in nutrients and microbial life were much higher and considered a higher value commodity (Adhikary, 2012). The type of worms that were commonly used were the white worms, red wigglers, and earthworms. These worms feed on the food scraps, and the material passes through the digestive tract to produce cocoons, also known as vermicompost granules. Earthworms in this method function as a crucial mediator that elevates the surface area accessibility to microorganisms, increasing the enzymatic actions and alteration of organic wastes' physical attributes (Jayaprakash et al., 2018).

Vermicompost contains various types of enzymes, such as amylase, lipase, cellulase, and chitinase. These enzymes help split the organic matter in the field and release the nutrients to the roots of plants. The secretion of chemicals from the worm's digestive tracts helps break down organic matter, so the product has higher nutrient saturation than its original form. The process of decomposition using vermicomposting was during the mesophilic phase of the process. Hence, the material that needs to be composted should be thermophilically composted before or after the worms are added to the compost pile. The product of decomposition was called vermicast (Figure 7).

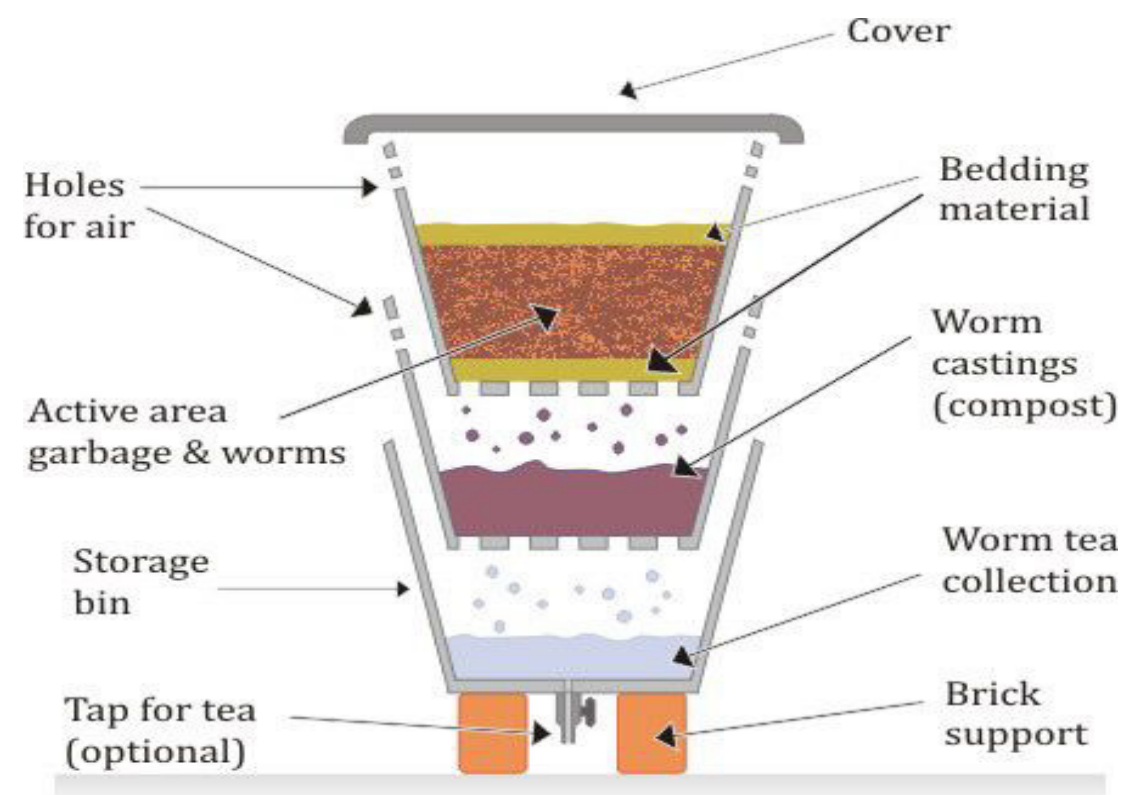

Figure 7. Vermicomposting bin using worms 
Veknesh Arumugam, Muhammad Heikal Ismail, Tharsini Amma Puspadaran, Winny Routray,

Ngadisih Ngadisih, Joko Nugroho Wahyu Karyadi, Bambang Suwignyo and Hatma Suryatmojo

Vermicompost can overcome soilborne plant diseases, such as root rot. This approach benefits rural agricultural lands, sustains the soil system, and ensures activity and alive. In addition, vermicomposting enrich nutrients in the soil and increases soil aeration, thus facilitating the survival and dispersal of the beneficial bacteria in such systems. However, this worm casting procedure will undoubtedly cause a handful amount of investment depending on the size of the operation. The problem associated with this method was the death of worms on a large or small scale. This situation might occur if the worms do not obtain sufficient food, food is too dry or too wet, or the bin is too hot (Adhikary, 2012).

Food waste treatment based on insects has been recognized increasingly as an environmentally friendly way to recycle resources and have the advantage of low installation costs. Furthermore, by a particular extraction procedure, insects can be an excellent source of protein (Choi et al., 2017; Lee et al., 2019). However, it was vital to keep conditions suitable for insects to survive and thrive as feed components, adequate temperatures, moisture, and acidity (Yoon et al., 2020). Of the insects, considerable attention has been paid to treating food waste with black soldier fly larvae (BSFL) (Lalander et al., 2019). The larvae breached various organic wastes using the powerful mouth and digestive enzymes (Cho et al., 2020; Pastor et al., 2015). As a result, organic wastes were effectively degraded, such as debris from rotten animals and plants (A. Singh \&
Kumari, 2019). BSFL may pupate in two weeks under ideal conditions for food supply, temperature, and moisture. BSFL composting benefits from rapid treatment of organic waste and reducing bacterial growth and odor (Pastor et al., 2015).

Black soldier fly's (BSF) larvae and prepupae were valuable sources of animal feed since they comprised $40 \%$ and $30 \%$ of protein and fat, respectively (Cummins et al., 2017; St-Hilaire et al., 2007). Other studies have shown that BSFL reduces cow manure nutrient concentrations, namely 30 to $50 \%$ nitrogen and 61 to $70 \%$ phosphorus (Myers et al., 2008). In many Asian countries, BSF raising was subject to appropriate natural conditions. BSF raising had an optimum temperature and relative humidity of $26-27{ }^{\circ} \mathrm{C}$ and $60-70$ $\%$, respectively (Barragan-Fonseca et al., 2017). The optimal substrates moisture content was $52-70 \%$ relative humidity (Barragan-Fonseca et al., 2017). The optimal light intensity was 135-200 $\mu \mathrm{mol} /$ $\mathrm{m}^{2}$ (Shumo et al., 2019), heavily influenced by seasons and the weather. Given the high temperatures and humidity of many Asian countries, including those of Southeast Asia, industries linked to the growth of BSF have high potential when implemented in those areas. The most effective ratio between the number of larvae and gram of substrate was reported to be 2:1 (Pastor et al., 2015) in the cultivation of BSFL (Figure 8).

The BSFL can be monitored by analyzing larval development aspects during the treatment of organic waste. Larvae were reported as 15 to 36.7 days, 
154 to $271 \mathrm{mg}, 2.3$ to $37 \mathrm{mg} / \mathrm{d}$, and 85.6 to $97.1 \%$, respectively (Julita et al., 2018; Liu et al., 2018; Myers et al., 2008; Pastor et al., 2015). The larvae were identified as the larval patient. The growth of BSFL depends on the type and conditions of the substrates. For example, when fed with food waste, fruits and vegetables, and poultry feed, BSFL survival was $87 \%, 90 \%$, and 93 $\%$, respectively. However, the survival rate was as low as $39 \%$ when fed with digested sludge (Lalander et al., 2019).

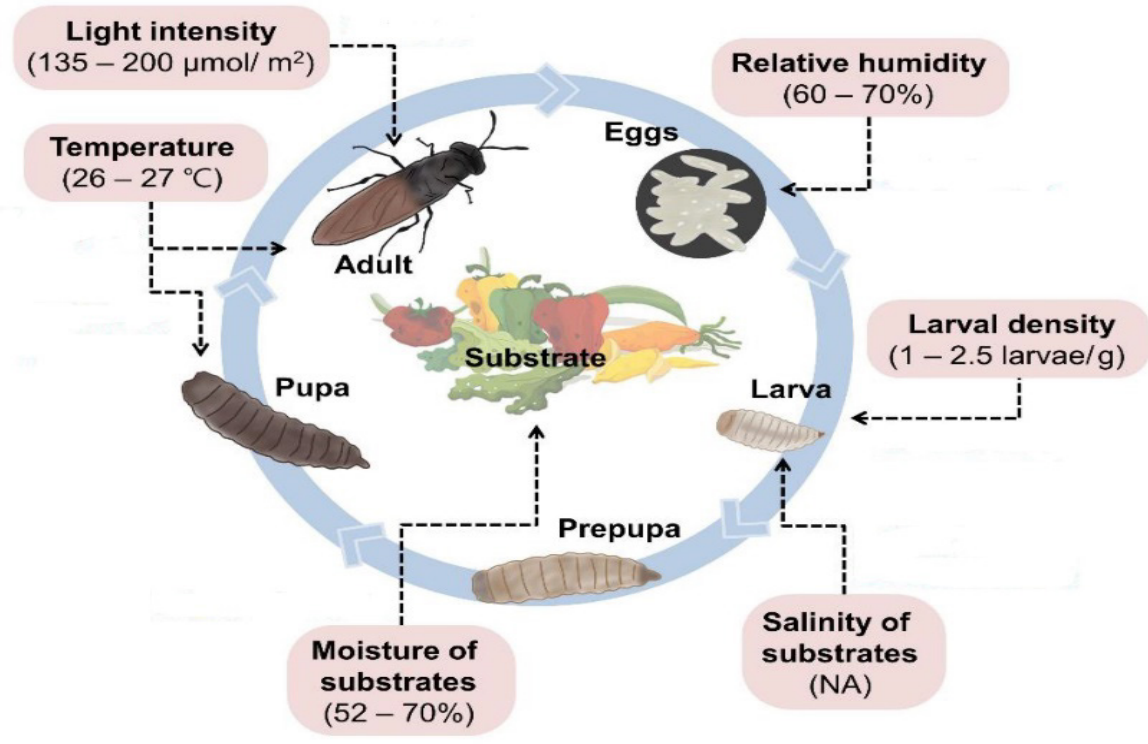

Figure 8. Vermicomposting using BSFL (Kim et al., 2021)

Berkeley Method. Berkeley method was a common and proven method to be used for green waste and food waste treatment. The method was a hot composting system that incorporates aerobic food waste treatment. This aerobic digestion process breaks up food waste and leftovers by various types of microorganisms, including bacteria and fungi, in the presence of oxygen into a hygienic, humus-rich substance. According to the Berkeley method, the procedure to conduct the composting method was by attaching a moveable mesh wire on the ground to form a compost bin. This method can produce finished compost in under a month. The rotation will continue until the compost smells sweet and, when touched, be as crumbly cold. It will then store the composted food waste in a safe place for further research. Based on the research conducted, the Berkeley method took one month or lesser to produce the bio-compost (Daud et al., 2016). Figure 9 shows the process of the Berkeley method conducted. 


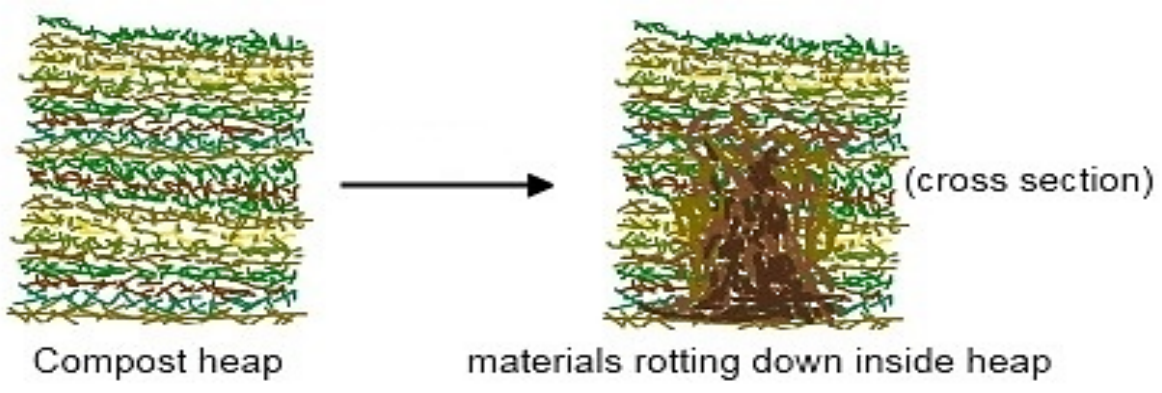

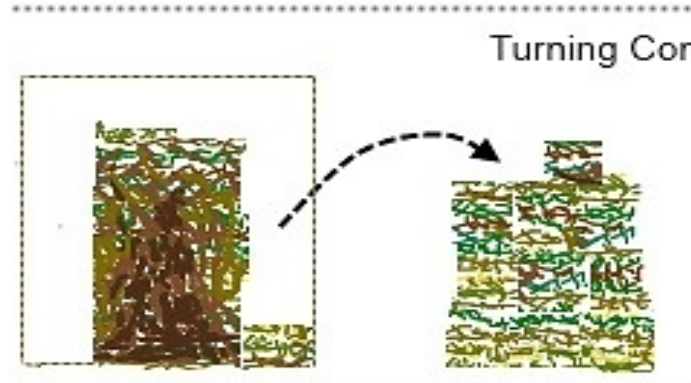

1. Remove outer layer \& pile to one side

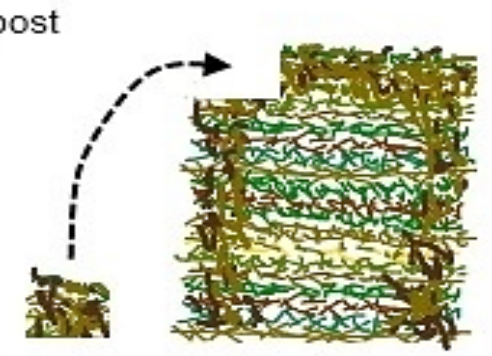

2. Pile inner layer to outside

Figure 9. Berkeley working method

Bokashi Method. The Bokashi method was a fermentation approach that uses anaerobic digestion, as shown in Figure 10. This system has originated in Japan, and the fertilizer mainly emphasizes the usage of rice bran, the meal of rapeseed, husk of rice, intense microorganism, sugar molasses, and water (Dou et al., 2012). The Bokashi method applies the usage of effective microorganisms to ferment the feedstocks. It focuses on using effective microorganisms (EM) to facilitate and accelerate the decomposition process.

EM was a mixture of microorganisms that primarily constitutes lactic acid bacteria that coexist in liquid media of $\mathrm{pH}$ 3.5. It was understood that EM improves soil and plant microbial variety, boosts field quality, and increases crop growth and quality. The benefits of integrated municipal organic waste recycling with EM technologies have been explored. The organic fertilizer produced from this approach can be utilized as soil nourishment, helps to increase the volume of water contained in the soil (Kumar et al., 2004). Bokashi compost method was also time efficient as compared to usual decomposing methods. Generally, the decomposition process of organic matter into simple organic compounds takes two to three months to be used as compost. On the other hand, the decomposition works faster within two to four weeks for Bokashi processing and does not leave behind foul odor and heat (Vinoth Kumar \& Kasturi Bai, 2008).

Other various studies supported Bokashi as soil nourishment in the agricultural 


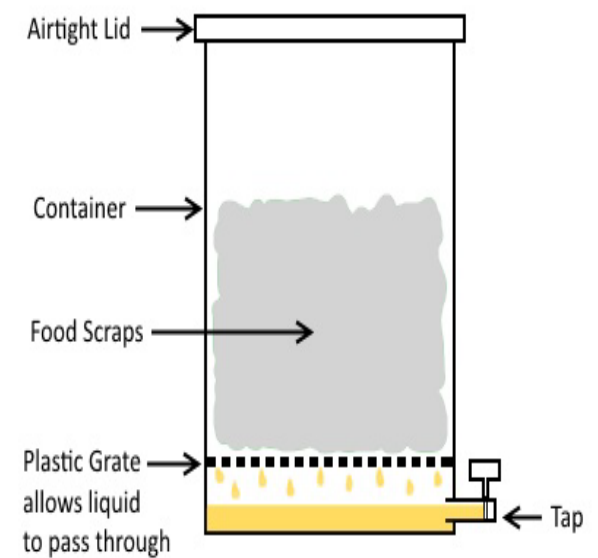

Figure 10. The visual aspect of Bokashi bin

sector. Bokashi's implementation in soil has further improved the concentration of $\mathrm{P}$ and $\mathrm{K}$ and the number of the plant stem, length, and diameter of an Alpinia purpurata plant. A study has also shown that Bokashi manure has elevated the growth of the okra plant. From research conducted to study Dana Mae Christel from the University of Vermont, a few advantages come with this method. Firstly, the EM for Bokashi treatments provides a longer-lasting plantavailable nitrogen nutrient than thermophilic compost and vermicompost. Then, this method also increases the aboveground height and biomass of plants. It was due to the compost's capability of providing a longer-term supply of nitrogen combined with a suitable amount of phosphorus and potassium for plant growth. Finally, this research concluded that Bokashi treatment was a suitable alternative fertility amendment for the organic vegetable production system (Jayaprakash et al., 2018).
Automated Biodigesters. Automated biodigesters were machinery that digested and processed food waste into nutrientrich fertilizers (Figure 11). The machine mixes and produces pre-compost within 24 hours process with a $90 \%$ weight reduction of waste. Automatic kitchen waste compost bin is one of the research technologies conducted at the University of Dalian, China. The designed equipment was equipped with crushing pre-treatment and waste fermentation. However, they also added that additional research was required to upgrade and improve the functional components to cover the kitchen waste disposal system fully. The greenhouse biogas plant was another type of biodigester practiced in many countries. A good number of biogas plants have been constructed in developing countries with a hollow sunlight sheet and an aluminum alloy frame support. The hollow sunlight sheet functioned to store the energy from the sunlight to aid the digestion process (Aschonitis et al., 2014; Garnett, 2012; Ma et al., 2020).

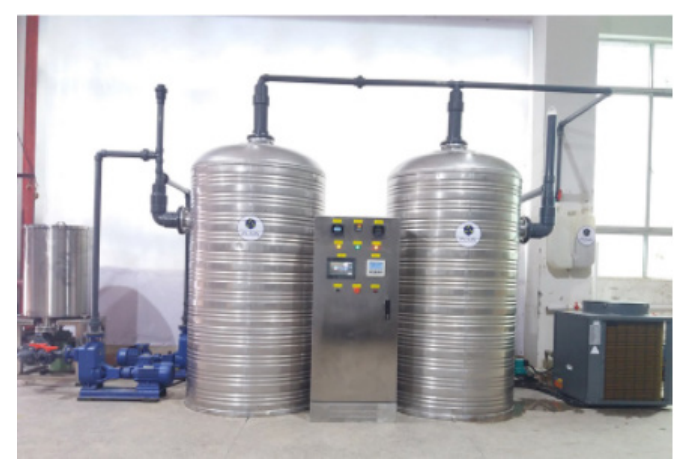

Figure 11. The visual aspect of automated biodigester 
Veknesh Arumugam, Muhammad Heikal Ismail, Tharsini Amma Puspadaran, Winny Routray,

Ngadisih Ngadisih, Joko Nugroho Wahyu Karyadi, Bambang Suwignyo and Hatma Suryatmojo

\section{NUTRIENT CONTENT IN BIO- COMPOST}

The bio compost that has been formed using the chosen method will then be tested by comparing its capability to nurture a specific species of plant. The prime function of bio compost was to improve soil fertility. The assessment and analysis of soil was a proficient measure of soil fertility. The typical soil test provides nitrogen $(\mathrm{N})$, phosphorus $(\mathrm{P})$, potassium $(\mathrm{K})$, calcium $(\mathrm{Ca})$, magnesium $(\mathrm{Mg}), \mathrm{pH}$, and base saturation concentration. Hence, the compost produced will be assessed on the $\mathrm{N}, \mathrm{P}$, and $\mathrm{K}$ content as it is the prime nutrients that aids in plant growth. NPK fertilizers formed from organic waste were essential to nurture healthy soil and plant growth. In addition, the nutrient levels, such as N, P, or K, should be periodically checked and tracked in potting soil stocks used for experiments (Che Jusoh et al., 2013; Dimkpa et al., 2017).

Based on a study conducted to study the effects of NPK fertilizers on the relative growth performance of maize grown in Nigeria, the researchers concluded in a positive remark stating that agro-ecological variety in the selected farmland should be focused on organic mineral fertilizers suggested. It includes the advanced nutrient control support scheme, especially by focusing on areas of low soil fertility. A couple of methods can be implemented to get a thorough analysis of soil test quality. One of the commonly used approaches was by utilizing the atomic absorption spectrophotometer. For the sample preparation, a mixture of hydrochloric acid and sulfuric acid will be utilized to dilute the fine particles of compost collected (Lü et al., 2010).

Another method that can be implied was also by using Multiwave 3000 microwave digestion system. The microwave digestion method can be conducted by following the EPA Method 3052. This approach aimed to decompose the sample by adding a judicious choice of combinations of acids, which can be done for most matrices. Auto analyzer machine was also another main method used to study the micronutrients content in soils and compost. This method was primarily practiced in biogeochemical-ecological research to analyze the composition of water and soil samples. For this approach, the method of Murphy-Riley was commonly used to analyze the potassium content in the soil. This method focuses on the reaction between ortho-phosphates and molybdate with antimony potassium tartrate as the catalyst. This reaction was then followed by the reduction with ascorbic acid at a $\mathrm{pH}$ below 1. The blue component formed will be measured at $880 \mathrm{~nm}$ to identify the concentration of potassium. Then, to analyze the nitrogen concentration, the copper-cadmium coil was set as non-active during analysis (Massri \& Labban, 2014; Moonrungsee et al., 2015).

The sample was mixed with an internal reference, lithium nitrate of fixed concentration, to identify potassium concentration in the compost. This product 
was then nebulized and flushed with a mixture of propane-air. The mixture was burned in the machine, and the result obtained was emission lines for potassium and lithium. The values obtained will be compared to the intensity of the emission generated by the lithium ions. It was to compensate for fluctuations in flame temperature, flow rate, and chemical interferences. Besides that, nutrient monitoring methods based on meters were also very common in the soil testing industry. The machine opts for remotely controlled equipment operationally like its laboratory collaborators using battery-operated nutrient-specific meters containing electrode sensors or fieldportable spectrometers and solution ion calibration (A. L. Singh et al., 2010; Patil \& Bodhe, 2011; R. P. Singh et al., 2011).

\section{GROWTH QUALITY OF PLANTS}

Organic farming was tremendously advantageous, thus making our development more economically feasible. Organic agriculture shall track the plague or the disease without preventing environmental degradation, avoid contamination, increase the productivity of land so far crops can contain nutrients, and allow for increased marketable prices (Najar et al., 2015; Ukoje $\&$ Yusuf, 2013). Vermicompost was one of the better planting organic mediums. Vermicompost was highly organic and may not contain any chemicals, indicating that they were environmentally sustainable. It was nutritional, and it released nutrients at a time, which quickly plants could consume by reducing their need for pesticide application because herbs and fewer pesticides were also safe since their pest and disease were not present. In addition, it offers an environmentally safe approach to mineral fertilizers due to the availability of comparatively significant quantities of crop growth and production micronutrients while offering an environmentally sustainable alternative (Lazcano \& Dominguez, 2014).

Organic farming, such as using vermicompost, could be a trend in sustainable agriculture to be an almost permanent practice for years to come since vermicompost releases nutrients at a slow pace, allowing fast absorption by plants and increasing the moisture keeping power of the soil resulting in improved quality of plant production. Furthermore, vermicompost usage for the significant production of vegetables can also fix the problems related to the disposal of wastes and overcome the lack of organic material on an acceptable basis. On the other hand, a reliable blend of pungent and inorganic sources of substances could have the potential to obtain an excellent financial result for follow-up plants with strong soil wellbeing (Abdelaziz et al., 2007).

Soil variation with mature and healthy compost, even with potted urban solid waste, was extensively analyzed, and the effects of breed plants on beans, black eye peas, okra, tomato, squash, eggplant, watermelon, corn, and chili pepper (Roe et al., 1993) were increased. The practices 
Veknesh Arumugam, Muhammad Heikal Ismail, Tharsini Amma Puspadaran, Winny Routray,

Ngadisih Ngadisih, Joko Nugroho Wahyu Karyadi, Bambang Suwignyo and Hatma Suryatmojo

for integrated nutrient management were an essential factor in the practical and costefficient management of the soil fertility in sugarcane growing. Sugar cane injectors can lead to higher soil fertility, growth, or return into merged organic and inorganics matter (including biological fertilizers).

Vermicompost can promote plant cultivation, root production, and hence nutritional uptake. With humic substances, which were the main component of soil organic matter, the shoot biomass will increase over the hormone effects on root elongation and plant development (Oworu et al., 2010). In conclusion, the addition of vermicompost will improve the availability of nutrients in the land and nutrient intake in plants. It can result in a direct or indirect influence. Direct results shall be given either by the nutrients accompanied with the composting manure. In this sense, indirect results were improved microbial action and preservation of flavor, enhanced soil structure, eating matter, and water quality. The behaviors of microbial materials may increase the mobilization of nutrients but may also contribute to the immobilization of nutrients. Thus, improving soil composition and restoring the plants' roots, with the more significant soil volumes (Zandonadi et al., 2007).

The parameters to assess the growth quality of plants that have been fertilized by different compost can be measured by measuring plant height, the number of leaves and branches, and the dry weight of the plant (Ibrahim et al., 2018). The plant height measurement was taken using a measuring strip from the floor to the tip of the highest growth point. Firstly, the height of the plants will be measured daily until the plant is fully mature. Then, the ruler was set at the base of the plant the height was recorded. The value was charged with both date and height values. Then for the number of leaves, the leaves were counted daily and recorded.

The grid counting method was an approach used to measure the size of leaves. This method will be conducted using grid paper was removed from the plant and put on a paper grid. Then, on grid paper, the outlines of the leaf were drawn by pencil. Finally, by measuring the grids occupied by the leaf, the area of the leaf was determined. This approach was precise, but it requires time and effort to place on many leaves. The leaf area and dry weight were calculated after the 30-days growth, the leaves' surface area and dry weight of the greens were measured. The leaves area was measured using an application named "Petiole." This application runs by calibrating the mobile camera with a Petiole Pad, and once the calibration is completed, the leaf is placed in front of the camera (Xiao et al., 2009). The leaf area was then measured automatically by the app, and the results obtained were recorded.

The gravimetric method was also one of the methods used for leaf area measurement (Aschonitis et al., 2014). The leaf was first removed from the plant and put on white paper for this process. Next, a paper was cut 
out based on leaf shape. Now this paper's weight is contrasted with that of the known area on the same page. This approach was laborious and time-consuming when used on several leaves. In addition, image processing methods are currently being used to calculate the leaf region easily and precisely. Leaf area was calculated using the following steps: acquisition of images, image pre-processing, leaf segmentation regions, region filling, and area calculations (Feng \& Chun, 2010). Other researchers use threshold-based segmentation to obtain the size of the leaf.

Kang et al. (2021) investigated the growth characteristics of Chinese cabbage using organic fertilizer (compost). As a result, the leaf length $(12.6$ to $12.9 \mathrm{~cm})$, root length (11.8 to $15.3 \mathrm{~cm})$, fresh weight (14.7 to $16.5 \mathrm{~g}$ ), and dry weight (3.4 to $3.9 \mathrm{~g}$ ) were increased after four weeks compared to plants without compost with lower parameters: length of leaf $(11.8 \mathrm{~cm})$, length of root $(9.3 \mathrm{~cm})$, fresh weight (13.4 g) and dry weight (2.5 g). Furthermore, in compost-treated plants, the level of stomach conductivity that measures water relations in a plant increased to $0.07 \pm 0.0 \mathrm{~mol} / \mathrm{m}^{2}$, showing that the treated plants can stand dryness or salinity stress.

Table 3 shows the effects of Bokashi compost on bell peppers plant growth. Tong et al. (2021) declared that the plant height difference could be due to a high level of sodium ion $\left(\mathrm{Na}^{+}\right)$in the medium of Bokashi that can cause salinity stress (López-Serrano et al., 2021). Nutrient deficiencies could also lead to slow growth. For example, Razaq et al. (2017) reported a nitrogen deficiency in soybean plants and mint plants (Mentha piperita). In both conventional (2.95 mm) and Bokashi-grown plants, there was no significant $(p \leq 0.05)$ difference in internode length $(2.65 \mathrm{~mm})$. In contrast, Bokashi plants $(p \leq 0.05)$ stems were significantly $(10.2 \mathrm{~mm})$ thicker than those of conventional plants $(7.3 \mathrm{~mm})$. Plant height explains that nutrient deficiencies and salinity may be associated with the Bokashi plant's thinner stem.

Shafique et al. (2021) stated that the maximum and significant increase in shoot length $(14 \pm 0.81 \mathrm{~cm})$, number of leaves $(12 \pm 0.0)$, the diameter of leaves $(4.66 \pm$ $0.23 \mathrm{~cm})$, length of leaves $(9.0 \pm 0.40 \mathrm{~cm})$, surface areas of leaves $\left(36.7 \pm 0.87 \mathrm{~cm}^{2}\right)$, length of the whole plant $(14.33 \pm 0.47$ $\mathrm{cm})$, and root length $(5.66 \pm 0.47 \mathrm{~cm})$, has been found in vermicompost germinating media. Furthermore, the results showed a significant increase of vermicompost in all vegetation growths and floral parameters, such as plant root volume $(15.66 \pm 0.81)$ and number of lateral plant growth $(9.00$ $\pm 0.81)$ and stemmed diameter $(1.0 \pm 0.0$ $\mathrm{cm})$, number of open flowers $(2.66 \pm 0.94)$, flower diameter $(9.00 \pm 0.81 \mathrm{~cm})$, fresh weight $(16.66 \pm 0.47 \mathrm{~g})$, number of flower buds $(7.00 \pm 0.81)$. 
Veknesh Arumugam, Muhammad Heikal Ismail, Tharsini Amma Puspadaran, Winny Routray,

Ngadisih Ngadisih, Joko Nugroho Wahyu Karyadi, Bambang Suwignyo and Hatma Suryatmojo

Table 3

Effect of Bokashi compost on bell pepper plant growth (Tong et al., 2021)

\begin{tabular}{cc}
\hline Parameters & Values \\
\hline Plant height $(\mathrm{mm})$ & $611.00 \pm 24.34$ \\
Stem diameter $(\mathrm{mm})$ & $7.32 \pm 0.81$ \\
Stem internode $(\mathrm{mm})$ & $2.60 \pm 0.10$ \\
Number of fruits per plant & $2.60 \pm 0.89$ \\
Fruit weight per plant $(\mathrm{kg})$ & $0.76 \pm 46.06$ \\
Fruit circumference $(\mathrm{mm})$ & $233.60 \pm 26.08$ \\
\hline
\end{tabular}

\section{CONCLUSION}

This review article has gathered most of the information that can be implemented in researching the effect of food waste and leftovers as compost on the growth quality of the plant. Firstly, many advantages can be obtained from composting food waste and leftover foods as a soil amendment. Furthermore, it was a promising alternative to produce fertilizer soon. From all the compost methods reviewed, the Bokashi method stands out as the most convenient approach for this research. This method tends to be more affordable and, at the same time, delivers results in a shorter period compared to the others. Although anaerobic biodigesters deliver the product within a considerably shorter period among all the approaches presented, the availability and cost seem to be the drawback for this method. However, the Bokashi method was generally affordable, and it was a technique well-practiced worldwide. The pivotal element in this composting method was Bokashi bran. Bokashi bran has a lower processing cost, and it was compatible with being used in diverse anaerobic designed environments. The function of the Bokashi bran in this process was to implement lactic acid bacteria to amplify the decomposition process in the vessel. This sequence of the procedure will be conducted by following the reference that has been reviewed in this article.

\section{ACKNOWLEDGEMENTS}

This study is a collaboration by researchers in Malaysia, Indonesia, and India. This research has received financial support from UC Seed Fund for Collaborative Research Grant (RBG19-1789), Knowledge Transfer Grant Scheme (Vote Number: 9437581), and UPM Publication Fund (Vote Number: 9001103).

\section{CONFLICT OF INTEREST}

The authors declare that they have no conflict of interest.

\section{REFERENCES}

Abdelaziz, M., Pokluda, R., \& Abdelwahab, M. (2007). Influence of compost, microorganisms and NPK fertilizer upon growth, chemical composition and essential oil production of 
Rosmarinus officinalis L. Notulae Botanicae Horti Agrobotanici Cluj-Napoca, 35(1), 86-90. https://doi.org/10.15835/nbha351261

Abdul Jalil, M. (2010). Sustainable development in Malaysia : A case study on household waste management. Journal of Sustainable Development, 3(3), 91-102.

Abdullah, N., \& Chin, N. L. (2010). Simplex-centroid mixture formulation for optimized composting of kitchen waste. Bioresource Technology, 101(21), 8205-8210. https://doi.org/10.1016/j. biortech.2010.05.068

Adhikary, S. (2012). Vermicompost, the story of organic gold: A review. Agricultural Sciences, 3(7), 905-917. https://doi.org/10.4236/ as. 2012.37110

Amin, M. E. M. H. (2011). Effect of different nitrogen sources on growth, yield and quality of fodder maize (Zea mays L.). Journal of the Saudi Society of Agricultural Sciences, 10(1), 17-23. https://doi.org/10.1016/j.jssas.2010.06.003

Andersen, J. K., Boldrin, A., Christensen, T. H., \& Scheutz, C. (2012). Home composting as an alternative treatment option for organic household waste in Denmark: An environmental assessment using life cycle assessmentmodelling. Waste Management, 32(1), 31-40. https://doi.org/10.1016/j.wasman.2011.09.014

Apagu, A. B. (2012). Recycling biodegradable waste using composting technique. Journal of Environmental Science and Resources Management, 4, 40-49.

Aschonitis, V. G., Papamichail, D. M., Lithourgidis, A., \& Fano, E. A. (2014). Estimation of leaf area index and foliage area index of rice using an indirect gravimetric method. Communications in Soil Science and Plant Analysis, 45(13), 1726-1740. https://doi.org/10.1080/00103624. 2014.907917
Barragan-Fonseca, K., Dicke, M., \& van Loon, J. (2017). Nutritional value of the black soldier fly (Hermetia illucens L.) and its suitability as animal feed - A review. Journal of Insects as Food and Feed, 3(2), 105-120. https://doi. org/10.3920/jiff2016.0055

Bashir, M. T., Ali, S., Ghauri, M., Adris, A., \& Harun, R. (2013). Impact of excessive nitrogen fertilizers on the environment and associated mitigation strategies. Asian Journal of Microbiology, Biotechnology and Environmental Sciences, 15(2), 213-221.

Blakeney, M. (2019). Food loss and waste and food security. In Food loss and food waste (pp. 1-26). Edward Elgar Publishing. https://doi. org/10.4337/9781788975391.00006

Bong, C. P. C., Goh, R. K. Y., Lim, J. S., Ho, W. S., Lee, C. T., Hashim, H., Abu Mansor, N. N., Ho, C. S., Ramli, A. R., \& Takeshi, F. (2017). Towards low carbon society in Iskandar Malaysia: Implementation and feasibility of community organic waste composting. Journal of Environmental Management, 203(Part 2), 679-687. https://doi.org/10.1016/j. jenvman.2016.05.033

Cabanillas, C., Stobbia, D., \& Ledesma, A. (2013). Production and income of basil in and out of season with vermicomposts from rabbit manure and bovine ruminal contents alternatives to urea. Journal of Cleaner Production, 47, 77-84. https://doi.org/10.1016/j.jclepro.2013.02.012

Che Jusoh, M. L., Abd Manaf, L., \& Abdul Latiff, P. (2013). Composting of rice straw with effective microorganisms (EM) and its influence on compost quality. Iranian Journal of Environmental Health Science and Engineering, 10, 17. https://doi.org/10.1186/1735-2746-10-17

Chen, Y. T. (2016). A cost analysis of food waste composting in Taiwan. Sustainability, 8(11), 1210. https://doi.org/10.3390/su8111210 
Veknesh Arumugam, Muhammad Heikal Ismail, Tharsini Amma Puspadaran, Winny Routray,

Ngadisih Ngadisih, Joko Nugroho Wahyu Karyadi, Bambang Suwignyo and Hatma Suryatmojo

Cho, S., Kim, C. H., Kim, M. J., \& Chung, H. (2020). Effects of microplastics and salinity on food waste processing by black soldier fly (Hermetia illucens) larvae. Journal of Ecology and Environment, 44, 7. https://doi.org/10.1186/ s41610-020-0148-x

Choi, B. D., Wong, N., \& Auh, J. H. (2017). Defatting and sonication enhances protein extraction from edible insects. Korean Journal for Food Science of Animal Resources, 37(6), 955-961. https://doi. org/10.5851/kosfa.2017.37.6.955

Cummins, V. C., Rawles, S. D., Thompson, K. R., Velasquez, A., Kobayashi, Y., Hager, J., \& Webster, C. D. (2017). Evaluation of black soldier fly (Hermetia illucens) larvae meal as partial or total replacement of marine fish meal in practical diets for Pacific white shrimp (Litopenaeus vannamei). Aquaculture, 473, 337-344. https:// doi.org/10.1016/j.aquaculture.2017.02.022

Daud, N. M., Khalid, S. A., Nawawi, W. N. W., \& Ramli, N. (2016). Producing fertilizer from food waste recycling using berkeley and bokashi method. Ponte Academic Journal, 72(4). https:// doi.org/10.21506/j.ponte.2016.4.11

Dimkpa, C., Bindraban, P., McLean, J. E., Gatere, L., Singh, U., \& Hellums, D. (2017). Methods for rapid testing of plant and soil nutrients. In E. Lichtfouse (Ed.), Sustainable agriculture reviews (pp. 1-43). Springer. https://doi.org/10.1007/9783-319-58679-3_1

Dou, L., Komatsuzaki, M., \& Nakagawa, M. (2012). Effects of Biochar, Mokusakueki and Bokashi application on soil nutrients, yields and qualities of sweet potato. International Research Journal of Agricultural Science and Soil Science, 2(8), 318-327.

Du, Y., Feng, H., Zhang, K., Hu, L. F., Fang, C. R., Shen, D. S., \& Long, Y. Y. (2014). Role of iron in $\mathrm{H}_{2} \mathrm{~S}$ emission behavior during the decomposition of biodegradable substrates in landfill. Journal of Hazardous Materials, 272, 36-41. https://doi. org/10.1016/j.jhazmat.2014.02.040
Ebner, J., Win, S. S., Hegde, S., Vadney, S., Williamson, A., \& Trabold, T. (2014). Estimating the biogas potential from colleges and universities. In Proceedings of the American Society of Mechanical Engineers 2014 8th International Conference on Energy Sustainability (Vol. 2, p. V002T04A005). ASME Publishing. https://doi. org/10.1115/ES2014-6433

Edwards, S., Asmelash, A., Araya, H., \& Egziabher, T. (2008). Impact of compost use on crop yields in Tigray, Ethiopia, 2000-2006 inclusive. https:// www.fao.org/3/ai434e/ai434e.pdf

Environmental Protection Agency. (2017). United States 2030 food loss and waste reduction goal. EPA.

Feng, T., \& Chun, W. (2010). Calculating the leaf-area based on non-loss correction algorithm. In 2010 International Conference of Information Science and Management Engineering (Vol. 1, pp. 7578). IEEE Publishing. https://doi.org/10.1109/ isme. 2010.54

Food and Agriculture Organization of the United Nations. (2011). Global food losses and food waste-Extent, causes and prevention. FAO.

Food and Agriculture Organization of the United Nations. (2013). Developments in forums of importance for the mandate of the Food and Agriculture Organization of the United Nations. FAO.

Food and Agriculture Organization of the United Nations. (2014). Save Food: Global Initiative on Food Loss and Waste Reduction. FAO.

Garnett, A. E. (2012). Food and yard waste compost as a nutrient source for corn [Master's thesis, Dalhousie University]. Dalhousie Theses and Dissertations. https://dalspace.library.dal.ca/ bitstream/handle/10222/14623/Garnett,\%20 Angela,\%20MSc,\%20AGRI,\%20April2012. pdf? sequence $=1$ 
Hanc, A., Szakova, J., \& Ochecova, P. (2014). Differences in the mobility of $\mathrm{Cd}, \mathrm{Cu}, \mathrm{Pb}$ and $\mathrm{Zn}$ during composting of two types of household bio-waste collected in four seasons. Bioresource Technology, 168, 204-213. https:// doi.org/10.1016/j.biortech.2014.01.125

Heikal Ismail, M., Ghazi, T. I. M., Hamzah, M. H., Manaf, L. A., Tahir, R. M., Mohd Nasir, A., \& Ehsan Omar, A. (2020). Impact of Movement Control Order (MCO) due to coronavirus disease (COVID-19) on food waste generation: A case study in Klang Valley, Malaysia. Sustainability, 12(21), 8848. https://doi.org/10.3390/ su12218848

Ibrahim, M., Rahman, N., \& Zain, N. (2018). Effect of nitrogen rates on growth and quality of water spinach (Ipomea aquatica). Annual Research and Review in Biology, 26(1), 1-12. https://doi. org/10.9734/arrb/2018/40352

Íñiguez-Covarrubias, G., Gómez-Rizo, R., RamírezMeda, W., \& de Jesús Bernal-Casillas, J. (2018). Composting of food and yard wastes under the static aerated pile method. Advances in Chemical Engineering and Science, 8(4), 271-279. https:// doi.org/10.4236/aces.2018.84019

Jayaprakash, S., Lohit, H. S., \& Abhilash, B. S. (2018). Design and development of compost bin for Indian kitchen. International Journal of Waste Resources, 8(1), 1000323. https://doi. org/10.4172/2252-5211.1000323

Jereme, I. A., Siwar, C., Begum, R. A., \& Abdul Talib, B. (2016). Addressing the problems of food waste generation in Malaysia. International Journal of Advanced and Applied Sciences, 3(8), 68-77. https://doi.org/10.21833/ijaas.2016.08.012

Jiménez-Antillón, J., Calleja-Amador, C., \& RomeroEsquivel, L. G. (2018). Food waste recovery with Takakura portable compost boxes in offices and working places. Resources, 7(4), 84. https://doi. org/10.3390/resources 7040084
Julita, U., Suryani, Y., Kinasih, I., Yuliawati, A., Cahyanto, T., Maryeti, Y., Permana, A. D., \& Fitri, L. L. (2018). Growth performance and nutritional composition of black soldier fly, Hermetia illucens (L.), (Diptera : Stratiomyidae) reared on horse and sheep manure. In IOP Conference Series: Earth and Environmental Science (Vol. 187, p. 012071). IOP Publishing. https://doi. org/10.1088/1755-1315/187/1/012071

Kadir, A. A., Ismail, S. N. M., \& Jamaludin, S. N. (2016). Food waste composting study from Makanan Ringan Mas. In IOP Conference Series: Materials Science and Engineering, Soft Soil Engineering International Conference 2015 (Vol. 136, p. 012057). IOP Publishing. https:// doi.org/10.1088/1757-899x/136/1/012057

Kang, S. M., Shaffique, S., Kim, L. R., Kwon, E. H., Kim, S. H., Lee, Y. H., Kalsoom, K., Aaqil Khan, M., \& Lee, I. J. (2021). Effects of organic fertilizer mixed with food waste dry powder on the growth of Chinese cabbage seedlings. Environments, 8(8), 86. https://doi.org/10.3390/ environments 8080086

Kasozi, G. N., Nkedi-Kizza, P., \& Harris, W. G. (2009). Varied carbon content of organic matter in Histosols, Spodosols, and Carbonatic soils. Soil Science Society of America Journal, 73(4), 1313-1318. https://doi.org/10.2136/ sssaj2008.0070

Khater, E. S. G. (2015). Some physical and chemical properties of compost. International Journal of Waste Resources, 5(1), 1000172.

Kim, C. H., Ryu, J., Lee, J., Ko, K., Lee, J. Y., Park, K. Y., \& Chung, H. (2021). Use of black soldier fly larvae for food waste treatment and energy production in Asian countries: A review. Processes, 9(1), 161. https://doi.org/10.3390/ pr9010161

Kumar, S., Mondal, A. N., Gaikwad, S. A., Devotta, S., \& Singh, R. N. (2004). Qualitative assessment of methane emission inventory from municipal 
Veknesh Arumugam, Muhammad Heikal Ismail, Tharsini Amma Puspadaran, Winny Routray,

Ngadisih Ngadisih, Joko Nugroho Wahyu Karyadi, Bambang Suwignyo and Hatma Suryatmojo

solid waste disposal sites: A case study. Atmospheric Environment, 38(29), 4921-4929. https://doi.org/10.1016/j.atmosenv.2004.05.052

Kurniawan, T. A., de Oliveira, J. P., Premakumara, D. G. J., \& Nagaishi, M. (2013). City-to-city level cooperation for generating urban co-benefits: The case of technological cooperation in the waste sector between Surabaya (Indonesia) and Kitakyushu (Japan). Journal of Cleaner Production, 58, 43-50. https://doi.org/10.1016/j. jclepro.2013.08.002

Lalander, C., Diener, S., Zurbrügg, C., \& Vinnerås, B. (2019). Effects of feedstock on larval development and process efficiency in waste treatment with black soldier fly (Hermetia illucens). Journal of Cleaner Production, 208, 211-219. https://doi. org/10.1016/j.jclepro.2018.10.017

Lazcano, C., \& Domínguez, J. (2014). The use of vermicompost in sustainable agriculture: Impact on plant growth and soil fertility. Soil Nutrients, 10(1-23), 187.

Lee, H. J., Kim, J. H., Ji, D. S., \& Lee, C. H. (2019). Effects of heating time and temperature on functional properties of proteins of yellow mealworm larvae (Tenebrio molitor L.). Food Science of Animal Resources, 39(2), 296-308. https://doi.org/10.5851/kosfa.2019.e24

Lekammudiyanse, L. M. M. U., \& Gunatilake, S. K. (2008). Efficiency of the household compost bin as a waste management technique in Sri Lanka (a case study in Gampaha Municipal Council area). International Journal of Basic and Applied Sciences, 10(1), 89-94.

Lih, T. M. (2015). Production of fertilizer using food wastes of vegetables and fruits [Unpublished Bachelor's dissertation]. Universiti Malaysia Sarawak.

Liu, Z., Minor, M., Morel, P. C. H., \& NajarRodriguez, A. J. (2018). Bioconversion of three organic wastes by black soldier fly (Diptera: Stratiomyidae) larvae. Environmental
Entomology, 47(6), 1609-1617. https://doi. org/10.1093/ee/nvy141

López-Serrano, L., Calatayud, N., López-Galarza, S., Serrano, R., \& Bueso, E. (2021). Uncovering salt tolerance mechanisms in pepper plants: A physiological and transcriptomic approach. BMC Plant Biology, 21(1), 169. https://doi. org/10.1186/s12870-021-02938-2

Lü, C., Ren, H., Zhang, Y., \& Shen, Y. (2010). Leaf area measurement based on image processing. In 2010 International Conference on Measuring Technology and Mechatronics Automation (Vol. 3, pp. 580-582). IEEE Publishing. https://doi. org/10.1109/icmtma.2010.141

Ma, L., Duan, T., \& Hu, J. (2020). Application of a universal soil extractant for determining the available NPK: A case study of crop planting zones in central China. Science of the Total Environment, 704, 135253. https://doi. org/10.1016/j.scitotenv.2019.135253

Massri, M., \& Labban, L. (2014). Comparison of different types of fertilizers on growth, yield and quality properties of watermelon (Citrllus lanatus). Agricultural Sciences, 5(6), 475-482. https://doi.org/10.4236/as.2014.56048

Melikoglu, M., Lin, C. S. K., \& Webb, C. (2013). Analyzing global food waste problem: Pinpointing the facts and estimating the energy content. Central European Journal of Engineering, 3(2), 157-164. https://doi. org/10.2478/s13531-012-0058-5

Moonrungsee, N., Pencharee, S., \& Jakmunee, J. (2015). Colorimetric analyzer based on mobile phone camera for determination of available phosphorus in soil. Talanta, 136, 204-209. https://doi.org/10.1016/j.talanta.2015.01.024

Mu, D., Horowitz, N., Casey, M., \& Jones, K. (2017). Environmental and economic analysis of an invessel food waste composting system at Kean University in the U. S. Waste Management, 59, 476-486. https://doi.org/10.1016/j. wasman.2016.10.026 
Muhammad Firdaus, A. R., Abu Samah, M. A., \& Abd Hamid, K. B. (2018). CHNS analysis towards food waste in composting. Journal CleanWAS, 2(1), 6-10. https://doi.org/10.26480/ jcleanwas.01.2018.06.10

Muruga, M., Arumugam, V., \& Heikal Ismail, M. (2021). Bio-compost behaviour as soil additive by food waste pretreatment on the growth of Abelmoschus esculentus L.: A systematic review. Pertanika Tropical Agricultural Science, 44(4), 825-844. https://doi.org/10.47836/pjtas.44.4.07

Myers, H. M., Tomberlin, J. K., Lambert, B. D., \& Kattes, D. (2008). Development of black soldier fly (Diptera: Stratiomyidae) larvae fed dairy manure. Environmental Entomology, 37(1), 11-15. https://doi.org/10.1093/ee/37.1.11

Najar, I. A., Khan, A. B., \& Hai, A. (2015). Effect of macrophyte vermicompost on growth and productivity of brinjal (Solanum melongena) under field conditions. International Journal of Recycling of Organic Waste in Agriculture, 4(2), 73-83. https://doi.org/10.1007/s40093015-0087-1

Oworu, O., Dada, O., \& Majekodunmi, O. (2010). Influence of compost on growth, nutrient uptake and dry matter partitioning of grain amaranths (Amaranthus hypochondriacus L.). Libyan Agriculture Research Center Journal International, 1(6), 375-383.

Palaniveloo, K., Amran, M. A., Norhashim, N. A., Mohamad-Fauzi, N., Peng-Hui, F., Hui-Wen, L., Kai-Lin, Y., Jiale, L., Chian-Yee, M. G., Jing-Yi, L., Gunasekaran, B., \& Razak, S. A. (2020). Food waste composting and microbial community structure profiling. Processes, 8(6), 723. https:// doi.org/10.3390/pr8060723

Pandey, P. K., Vaddella, V., Cao, W., Biswas, S., Chiu, C., \& Hunter, S. (2016). In-vessel composting system for converting food and green wastes into pathogen free soil amendment for sustainable agriculture. Journal of Cleaner Production,
139, 407-415. https://doi.org/10.1016/j. jclepro.2016.08.034

Paritosh, K., Kushwaha, S. K., Yadav, M., Pareek, N., Chawade, A., \& Vivekanand, V. (2017). Food waste to energy: An overview of sustainable approaches for food waste management and nutrient recycling. BioMed Research International, 2017, 2370927. https://doi. org/10.1155/2017/2370927

Pastor, B., Velasquez, Y., Gobbi, P., \& Rojo, S. (2015). Conversion of organic wastes into fly larval biomass: Bottlenecks and challenges. Journal of Insects as Food and Feed, 1(3), 179-193. https:// doi.org/10.3920/jiff2014.0024

Patil, S., \& Bodhe, S. (2011). Betel leaf area measurement using image processing. International Journal on Computer Science and Engineering, 3(7), 2656-2660.

Praveen S. (2009). Analysis of micronutrients in soil by using AA 800 atomic absorption spectrophotometer. https://resources. perkinelmer.com/lab-solutions/resources/docs/ APP_MicronutrientsInSoilbyAA.pdf

Razaq, M., Zhang, P., Shen, H. L., \& Salahuddin. (2017). Influence of nitrogen and phosphorous on the growth and root morphology of Acer mono. PLOS One, 12(2), e0171321. https://doi. org/10.1371/journal.pone.0171321

Rich, N., \& Bharti, A. (2015). Assessment of different types of in-vessel composters and its effect on stabilization of MSW compost. International Research Journal of Engineering and Technology, 2(3), 805-813.

Risse, L. M., \& Faucette, B. (2009). Food waste composting: Institutional and industrial applications. https://extension.uga.edu/ publications/detail.html?number=B1189

Roe, N. E., Stoffella, P. J., \& Bryan, H. H. (1993). Utilization of MSW compost and other organic mulches on commercial vegetable crops. Compost 
Veknesh Arumugam, Muhammad Heikal Ismail, Tharsini Amma Puspadaran, Winny Routray,

Ngadisih Ngadisih, Joko Nugroho Wahyu Karyadi, Bambang Suwignyo and Hatma Suryatmojo

Science and Utilization, 1(3), 73-84. https://doi. org/10.1080/1065657X.1993.10757892

Saer, A., Lansing, S., Davitt, N. H., \& Graves, R. E. (2013). Life cycle assessment of a food waste composting system: Environmental impact hotspots. Journal of Cleaner Production, 52, 234-244. https://doi.org/10.1016/j. jclepro.2013.03.022

Shumo, M., Khamis, F., Tanga, C., Fiaboe, K., Subramanian, S., Ekesi, S., van Huis, A., \& Borgemeister, C. (2019). Influence of temperature on selected life-history traits of black soldier fly (Hermetia illucens) reared on two common urban organic waste streams in Kenya. Animals, 9(3), 79. https://doi.org/10.3390/ani9030079

Singh, A., \& Kumari, K. (2019). An inclusive approach for organic waste treatment and valorization using black soldier fly larvae: A review. Journal of Environmental Management, 251, 109569. https://doi.org/10.1016/j.jenvman.2019.109569

Singh, A. L., Jat, R. S., Chaudhari, V., Bariya, H., \& Sharma, S. J. (2010). Toxicities and tolerance of mineral elements boron, cobalt, molybdenum and nickel in crop plants. Plant Stress, 4(2), 31-56.

Singh, R. P., Singh, P., Ibrahim, M. H., \& Hashim, R. (2011). Land application of sewage sludge: Physicochemical and microbial response. In D. Whitacre (Ed.), Reviews of environmental contamination and toxicology (Vol. 214, pp. 41-61). Springer. https://doi.org/10.1007/9781-4614-0668-6_3

Shafique, I., Andleeb, S., Aftab, M. S., Naeem, F., Ali, S., Yahya, S., Ahmed, F., Tabasum, T., Sultan, T., Shahid, B., Khan, A. H., Islam, G. U., \& Abbasi, W. A. (2021). Efficiency of cow dung based vermi-compost on seed germination and plant growth parameters of Tagetes erectus (Marigold). Heliyon, 7(1), e05895. https://doi.org/10.1016/j. heliyon.2020.e05895
St-Hilaire, S., Sheppard, C., Tomberlin, J. K., Irving, S., Newton, L., McGuire, M. A., Mosley, E. E., Hardy, R. W., \& Sealey, W. (2007). Fly prepupae as a feedstuff for rainbow trout, Oncorhynchus mykiss. Journal of the World Aquaculture Society, 38(1), 59-67. https://doi.org/10.1111/ j.1749-7345.2006.00073.x

Thenabadu, M., Abeyweera, R., Jayasuriya, J., \& Senanayake, N. S. (2015). Anaerobic digestion of food and market waste; waste characterization and biomethane potential: A case study in Sri Lanka. SLEMA Journal, 18(2), 29-33. https:// doi.org/10.4038/slemaj.v18i2.18

Tong, R. C., Whitehead, C. S., \& Fawole, O. A. (2021). Effects of conventional and bokashi hydroponics on vegetative growth, yield and quality attributes of bell peppers. Plants, 10(7), 1281. https://doi.org/10.3390/plants10071281

Toumi, R. (2017). Design of a composting bin to convert aui 's biomass to an organic feltilizer [Unpublished Master's dissertation]. Al Khawayn University.

Ukoje, J., \& Yusuf, R. (2013). Organic fertilizer: The underestimated component in agricultural transformation initiatives for sustainable small holder farming in Nigeria. Ethiopian Journal of Environmental Studies and Management, 6(6), 794-801. https://doi.org/10.4314/ejesm.v6i6.10s

Vinoth Kumar, K., \& Kasturi Bai, R. (2008). Solar greenhouse assisted biogas plant in hilly region - A field study. Solar Energy, 82(10), 911-917. https://doi.org/10.1016/j.solener.2008.03.005

Waqas, M., Nizami, A. S., Aburiazaiza, A. S., Barakat, M. A., Rashid, M. I., \& Ismail, I. M. I. (2018). Optimizing the process of food waste compost and valorizing its applications: A case study of Saudi Arabia. Journal of Cleaner Production, 176, 426-438. https://doi. org/10.1016/j.jclepro.2017.12.165

Warman, P. R., Rodd, A. V., \& Hicklenton, P. (2009). The effect of MSW compost and fertilizer on 
extractable soil elements and the growth of winter squash in Nova Scotia. Agriculture, Ecosystems and Environment, 133(1-2), 98-102. https://doi.org/10.1016/j.agee.2009.05.010

Xiao, Y., Zeng, G. M., Yang, Z. H., Shi, W. J., Huang, C., Fan, C. Z., \& Xu, Z. Y. (2009). Continuous thermophilic composting (CTC) for rapid biodegradation and maturation of organic municipal solid waste. Bioresource Technology, 100(20), 4807-4813. https://doi.org/10.1016/j. biortech.2009.05.013

Yang, L., Li, F., \& Chu, H. (2014). Effects of food waste compost on soil microbial populations, tomato yield, and tomato quality. Communications in Soil Science and Plant Analysis, 45(8), 1049-1058. https://doi.org/10.1080/00103624. 2014.884103
Yoon, C. H., Jeon, S. H., Ha, Y. J., Kim, S. W., Bang, W. Y., Bang, K. H., Gal, S. W., Kim, I. S., \& Cho, Y. S. (2020). Functional chemical components in Protaetia brevitarsis larvae: Impact of supplementary feeds. Food Science of Animal Resources, 40(3), 461-473. https://doi. org/10.5851/kosfa.2020.e25

Zandonadi, D. B., Canellas, L. P., \& Façanha, A. R. (2007). Indolacetic and humic acids induce lateral root development through a concerted plasmalemma and tonoplast $\mathrm{H}^{+}$pumps activation. Planta, 225(6), 1583-1595. https:// doi.org/10.1007/s00425-006-0454-2 
